Prepared in cooperation with the U.S. Army Corps of Engineers

\title{
A Standard Operating Procedure for the Preparation of Purposely Killed Juvenile Salmon Used to Test Survival Model Assumptions
}

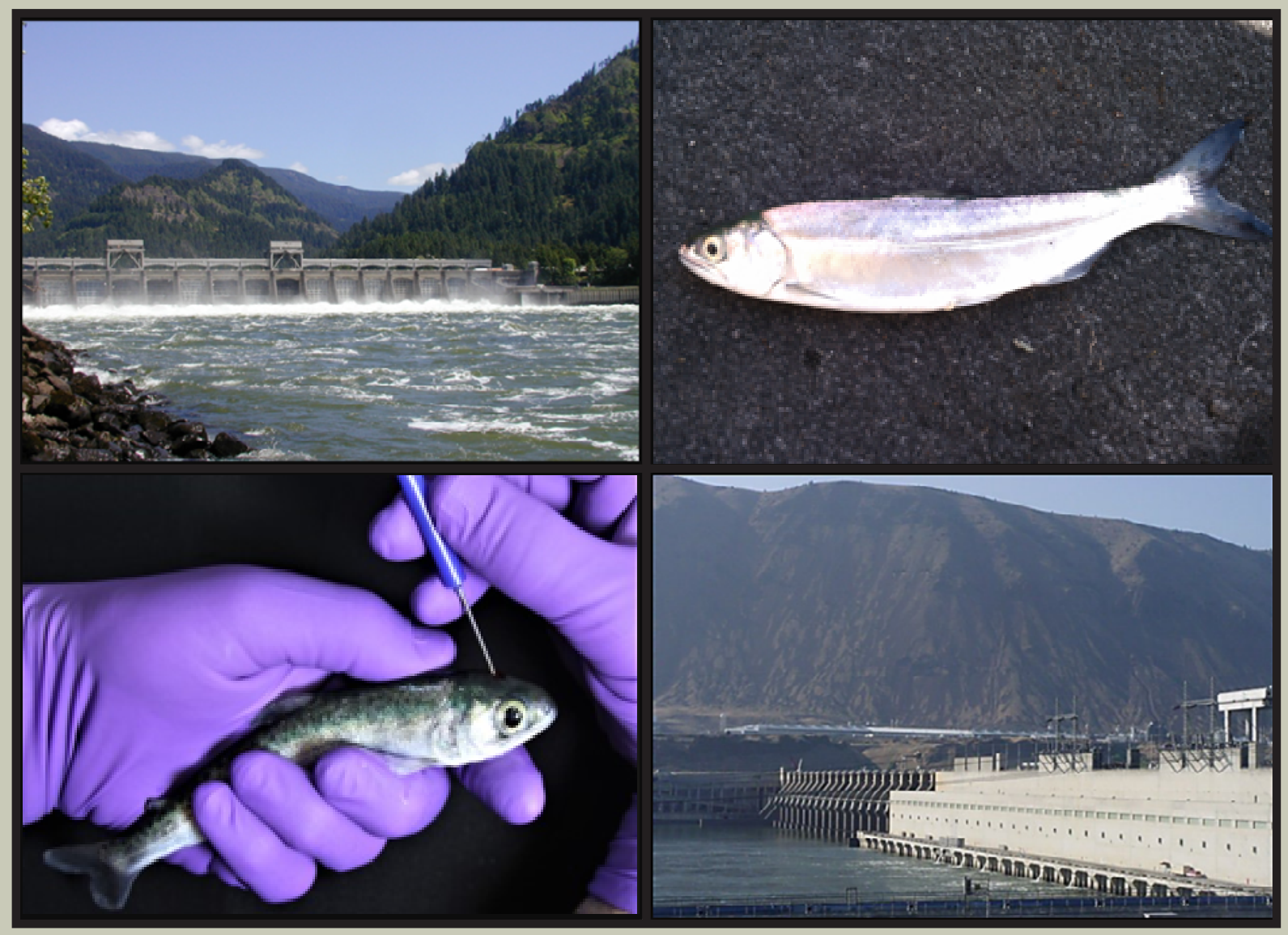

Open-File Report 2020-1083 
Cover (clockwise from top left): Bonneville Dam spillway, Washington, 2002; juvenile Chinook salmon (Oncorhynchus tshawytscha); juvenile Chinook salmon prior to pithing, 2020; John Day Dam, Oregon, 2003. All photographs by Collin Smith, U.S. Geological Survey. 


\section{A Standard Operating Procedure for the Preparation of Purposely Killed Juvenile Salmon Used to Test Survival Model Assumptions}

By Ryan G. Tomka, Theresa L. Liedtke, Conrad Frost, and Collin D. Smith

Prepared in cooperation with the U.S. Army Corps of Engineers

Open-File Report 2020-1083 


\section{U.S. Department of the Interior \\ DAVID BERNHARDT, Secretary}

\section{U.S. Geological Survey James F. Reilly II, Director}

U.S. Geological Survey, Reston, Virginia: 2020

For more information on the USGS-the Federal source for science about the Earth, its natural and living resources, natural hazards, and the environment-visit https://www.usgs.gov/ or call 1-888-ASK-USGS (1-888-275-8747).

For an overview of USGS information products, including maps, imagery, and publications, visit https://store.usgs.gov/.

Any use of trade, firm, or product names is for descriptive purposes only and does not imply endorsement by the U.S. Government.

Although this information product, for the most part, is in the public domain, it also may contain copyrighted materials as noted in the text. Permission to reproduce copyrighted items must be secured from the copyright owner.

Suggested citation:

Tomka, R.G., Liedtke, T.L., Frost, C., and Smith, C.D., 2020, A standard operating procedure for the preparation of purposely killed juvenile salmon used to test survival model assumptions: U.S. Geological Survey Open-File Report 2020-1083, 11 p., https://doi.org/10.3133/ofr20201083.

ISSN 2331-1258 (online) 


\section{Contents}

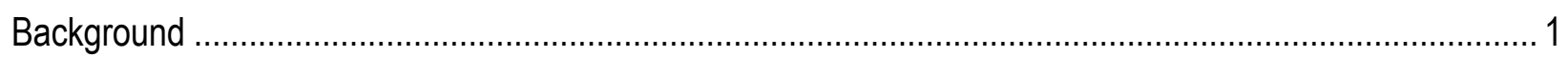

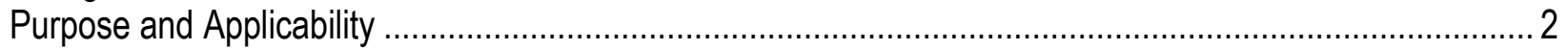

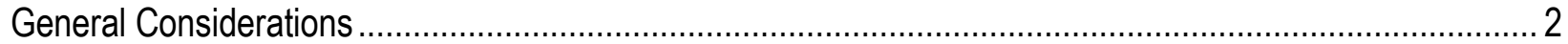

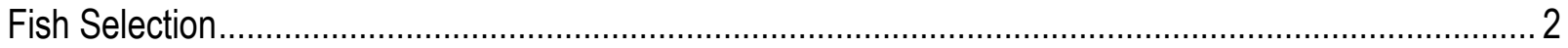

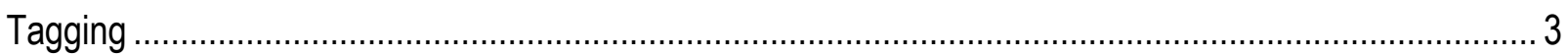

Standard Operating Procedure Execution …………………................................................ 3

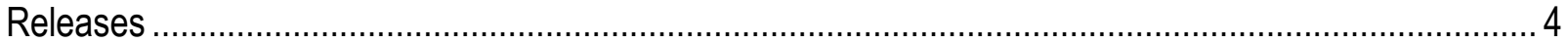

Quality Assurance/Quality Control Procedures .............................................................................. 4

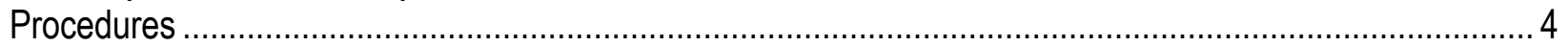

Exposure to High Dose Anesthetic Bath ....................................................................................... 4

Destroy the Brain by Pithing ................................................................................................. 5

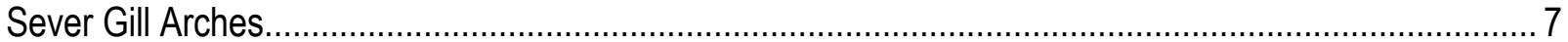

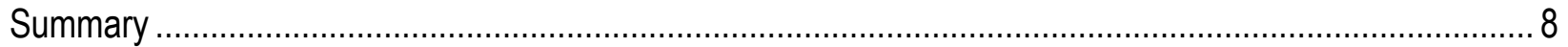

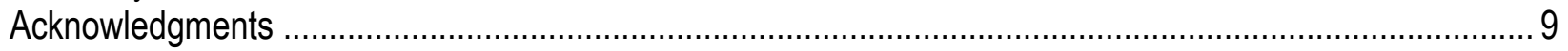

References Cited .................................................................................................................

Appendix 1. An Example Quality Assurance/Quality Control Dead Fish Standard Operating

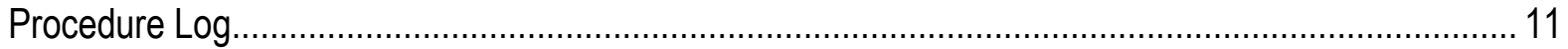

\section{Figures}

1. Photograph depicting an example 19-liter perforated recovery container .............................................5

2. Photograph depicting the initiation (first phase) of the pithing procedure on a juvenile salmon ................. 6

3. Photograph depicting the second phase of the pitching procedure on a juvenile salmon ..........................6

4. Photograph depicting juvenile salmon placement for severing gill arches ............................................... 7

5. Photograph depicting scissors being used to sever the gill arches of a juvenile salmon. .......................... 8

6. Photograph depicting a juvenile salmon with four severed gill arches................................................... 8

\section{Conversion Factors}

International System of Units to U.S. customary units

\begin{tabular}{lccc}
\hline & Multiply & By & To obtain \\
\hline & & Volume & \\
\hline liter (L) & 33.81402 & ounce, fluid (fl. oz) & \\
\hline
\end{tabular}

\section{Supplemental Information}

Concentrations of chemical constituents in water are given in either milligrams per liter $(\mathrm{mg} / \mathrm{L})$ or micrograms per liter $(\mu \mathrm{g} / \mathrm{L})$. 
This page intentionally left blank. 


\title{
A Standard Operating Procedure for the Preparation of Purposely Killed Juvenile Salmon Used to Test Survival Model Assumptions
}

\author{
By Ryan G. Tomka, Theresa L. Liedtke, Conrad Frost, and Collin D. Smith
}

\section{Background}

Telemetry is a powerful approach for monitoring the movements and behavior of animals. Both radio and acoustic telemetry are commonly used in fisheries research, and the development of miniature transmitters has enabled studies of small fishes and their life stages. The detailed data that may be generated from telemetry studies can be used within a markrecapture framework to estimate survival. When the unique signal for a given transmitter is detected at least once at a specific location and time, it is considered to be a "capture" event. Survival modeling, however, relies on several assumptions: the survival of tagged animals is the same as untagged animals, the fate of each tagged animal is independent of the fate of other tagged animals, and the status of the animal (alive or dead) is known without error (Perry and others, 2012). Specifically, for the last assumption, the models assume that all detections are of live animals. Dead animals must not be detected and interpreted as being alive.

In the Columbia River Basin, telemetry has been used on a large scale to monitor the outmigration of juvenile Pacific salmon (Oncorhynchus spp.) as they move downstream past a series of hydroelectric dams. Survival to and through the dams is commonly estimated from the detailed data collected using intensive telemetry monitoring arrays. To ensure that survival estimates generated from telemetry data are defensible, model assumptions, where possible, are tested. One approach used to test the assumption that only live fish are detected at monitoring stations is to release purposely killed fish. Detection records are then reviewed, and if any dead fish were detected, adjustments can be made to the monitoring array (fore example moving further from the fish release location) to better comply with model assumptions.

This document describes a standard operating procedure (SOP) for the preparation of purposely killed juvenile salmon, implanted with telemetry transmitters, to be released into rivers, lakes, or streams to test one of the survival model assumptions. Procedures for releases of purposely killed fish (hereinafter dead fish releases) were developed by staff from the U.S. Geological Survey's Columbia River Research Laboratory, on the basis of laboratory experiments and practical experience with telemetry studies in the Columbia River Basin (Counihan and others, 2006a, 2006b; Perry and others, 2006). Initially, we used extended exposure to high dose anesthetic baths to euthanize fish for dead fish releases. This approach was selected on the basis of euthanization procedures described in the literature for studies that required an effective and rapid procedure, such as stress physiology assessments. Ultimately, this technique was deemed insufficient because detection records suggested that some fish seemed to revive and continue their migration with limited effect. That is, the detection histories of dead 
fish were very similar to those of live fish (see, for example, Counihan and others, 2006a). To overcome this challenge, we adapted our procedures to require a combination of euthanization procedures on individual fish to ensure that there was no opportunity for revival. Havn and others (2017) also used a combination of euthanization procedures for dead fish releases in Germany. This SOP has been used by the U.S. Geological Survey to test survival model assumptions in several field studies and has consistently performed well (Beeman and others, 2010, 2012). In addition, limited laboratory tests were completed to ensure that no live juvenile salmon were found in holding tanks for 24 hours following the procedures described in this SOP (U.S. Geological Survey unpublished data).

\section{Purpose and Applicability}

The purpose of this document is to provide guidelines and procedures for dead fish releases used to test survival model assumptions. This SOP is defined specifically for juvenile salmonids and can be applied in any type of telemetry study: radio, acoustic, or passive (e.g. passive integrated transponder). In addition, a range of transmitter attachment techniques can be accommodated by the SOP, including surgical implantation, gastric implantation, or external attachment. The SOP could be adapted to provide guidance for other species or life stages by modifying the approach on the basis of the general considerations outlined in this report because they are broadly applicable to all fish.

\section{General Considerations}

This document assumes that dead fish releases will be part of a larger study where live fish equipped with transmitters are released and monitored. In this type of setting, fish for a dead fish release should be selected using the same criteria and handled the same as live study fish, except for the euthanization procedures. The fish selected for a dead fish release should have similar physical attributes as the live fish in the study so that they have similar drift properties. Specifically, there should not be physical distortion of the dead fish that may influence the way they would drift. Extended exposure to high dosage anesthetic meets these requirements well, but as previously noted, may not consistently ensure that fish are dead. This SOP requires pithing and severed gill arches in combination with an extended exposure to high dose anesthetic to ensure fish are dead, with limited distortion to the body.

\section{Fish Selection}

Fish selected for dead fish releases should be of similar size and source as live study fish, and they must be purposely killed. It can be tempting, especially when working in settings where fish numbers may be limited, to select moribund fish or fish that have recently died for use in dead fish releases. However, this approach should be avoided because these fish quickly become rigid after death and could be partially decomposed, both of which will likely influence their drift properties after release. Using a different fish source or a different size class of dead fish compared to live study fish could have similar consequences. To defensibly test survival model assumptions, the capture, collection, and holding procedures for dead fish should match those of live fish used in the study. It is advisable that up to the point of tagging, fish destined for use in dead fish releases not be segregated in any way from other study fish. 


\section{Tagging}

Tagging and handling procedures established for the study should be applied to fish destined for dead fish releases without modification. If possible, avoid designating fish for either live or dead fates until just prior to release, so fate is unknown during tagging. This approach avoids any potential bias during the tagging and handling steps. For example, if it is known that a group will be killed prior to release, shortcuts or reduced rigor might incidentally occur in aseptic technique (reduced antiseptic use), surgical execution (poor incision or suture closure), or good handling techniques (aggressive netting, excessive time out of water). These potential deviations from standard procedures, although incidental, could increase the stress response of fish designated for dead fish releases, or make them more vulnerable to disease or mortality.

\section{Standard Operating Procedure Execution}

Execute the SOP on fish randomly selected from a group of live tagged fish. This approach will help to ensure that all collection, holding, tagging, and recovery procedures for dead fish are identical to those used for live study fish. Therefore, comparisons between the live fish and dead fish will be more defensible.

The SOP should be executed just prior to release with detailed documentation. For each step of the SOP, one person should execute the procedure (the implementor) while another person observes (the observer) then certifies that the steps were properly completed. Both the implementor and the observer then document their activities on a datasheet or log (see appendix 1 for an example SOP $\log$ ). The time when procedures were initiated and completed should be recorded, along with water quality parameters because, water temperature or other related factors could influence the anesthesia response. It is important to be rigorous in execution of the SOP by confirming the anesthetic is not expired, confirming correct anesthetic dosage, and using timers to accurately measure anesthesia exposure duration.

The anesthesia procedures should be executed in a manner that prevents changes to the swim bladder volume and avoids differences in buoyancy between dead and live study fish. Juvenile salmon, and other fishes, can be irritated by high concentration anesthetic baths. Fish become very active, swimming fast and jumping to attempt escape. Fish tend to be surface oriented, gulping air during these active avoidance behaviors, which can result in inflated swim bladders and overall increased buoyancy compared to fish that were not exposed to high dose anesthetic. To avoid buoyancy changes, it is recommended that a screen is put in place in the container holding the fish prior to the addition of anesthesia. The screen should be positioned below the air-water interface so that fish cannot get access to air. Although the screens eliminate buoyancy changes, the avoidance behaviors will still occur, now in a smaller volume of water due to the screen. Therefore, the screen should be carefully checked to ensure it has smooth surfaces and a good fit in the container to avoid injury to fish. As described in the SOP, some of the irritation commonly experienced by fish can be reduced by buffering acidic anesthetic baths.

Several of the SOP procedures require manual dexterity and precision that can be readily improved with practice. We recommend that personnel planning to execute the SOP practice the pithing and gill severing techniques in advance of conducting them for a dead fish release.

Practice will improve the likelihood that dead fish are not distorted unnecessarily during pithing, that all gill arches are severed as prescribed, and procedures are executed smoothly and effectively. 


\section{Releases}

Dead fish should be released using the same procedures, locations, and timing as live study fish. The number of dead fish released will depend on the individual study design. Our approach has been to release a small number of dead fish with each release of live fish throughout the study in order to capture a range of river flow conditions. Another approach might be to target high flow conditions in order to maximize the potential for downstream drift. It is advisable that every dead fish release also include some live fish, but not every live fish release needs to include dead fish.

\section{Quality Assurance/Quality Control Procedures}

The SOP describes several quality assurance/quality control (QA/QC) measures to ensure all critical steps are observed by at least two individuals. These measures were included on the basis of our early experience with ineffective euthanization and questions that arose about whether the SOP was flawed or simply not executed with sufficient rigor. Although QA/QC steps are often seen as unnecessary additions to field procedures, we find them to be critical in documenting the rigorous and thorough execution of the SOP and in providing defensible dead fish releases to test model assumptions.

\section{Procedures}

Juvenile salmon for use in a dead fish release should be selected from the group of fish tagged for live fish releases, following a recommended 18-36 hour post-tagging holding period (Liedtke and Wargo-Rub, 2012; Liedtke and others, 2012). Log the time and personnel involved when the SOP is initiated (see appendix 1 for example log). Any fish that are dead, moribund, or demonstrating atypical behavior (for example, weak swimming, poor orientation, sluggish response) should not be selected for dead fish releases. For the purposes of this SOP, we assume that tagged fish will be placed into perforated 19-liter recovery containers immediately after tagging and held in these containers during the recovery period. Although the size of the container is not critical, the ideal approach is to place tagged fish into a portable recovery container that can be transported to the release location without any further netting or transfer of the fish (Liedtke and Wargo-Rub, 2012; Liedtke and others, 2012).

\section{Exposure to High Dose Anesthetic Bath}

Remove the recovery container from the water and insert a screen below the surface of the water in the container to eliminate access to the air-water interface (fig.1). The screen is designed to prevent fish from gulping air, which can occur when they respond to the high dose anesthetic that will be added. Ensure that the screen fits tightly along the edges of the container so that fish cannot move past the screen. The screen should be smooth so that fish do not become descaled or otherwise injured if they contact the screen. We use a center rod to support the screen and to facilitate insertion and removal (fig. 1). 


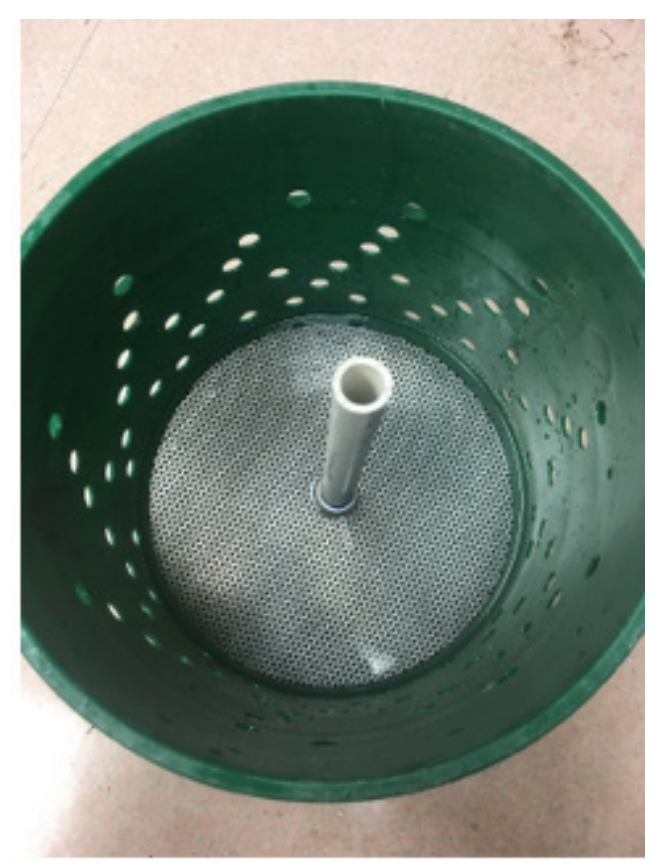

Figure 1. An example 19-liter perforated recovery container. Container holds 7 liters of water with a screen positioned just below the water surface.

With the screen in place, add anesthetic to the recovery container and record the time. Starting a timer is useful so that the exact exposure duration is documented. The final working concentration of the anesthetic bath should be 200 milligrams per liter of tricaine methanesulfonate (MS-222), buffered with an equal concentration of sodium bicarbonate. Other anesthetics may be used in concentrations sufficient to euthanize fish within less than 5 minutes. Fish should remain in the anesthesia bath for 30 minutes, with the screen in place throughout the exposure period. Following the 30-minute exposure, stop the exposure timer, record the exposure duration, and remove the screen to observe fish for any signs of life. If the SOP was executed rigorously, with MS-222 at full efficacy and at the prescribed dosage, fish should not show any signs of life. The potential for fish to revive happens only when they are removed from an anesthetic bath and placed into fresh water. Document the findings of the exam on the log (appendix 1).

\section{Destroy the Brain by Pithing}

Destroy the brain of the fish by pithing. Remove a fish from the anesthetic bath and insert a dissecting probe through the surface of the fish's head between and directly behind the eyes (fig. 2), with the probe oriented toward the caudal area. Make a clean entry to minimize injury to the exterior of the fish. Push the probe toward the caudal area until the back of the cranium is felt. Do not force the probe beyond the point of resistance. With the probe positioned at the posterior (caudal) end of the cranium, move the probe laterally a few degrees to the left and the right, using the initial entry hole as a fulcrum. Gently pull the probe back slightly (but do not remove it from the cranium) and rotate the tip so that it is pointed toward the snout of the fish (fig. 3). Push the probe forward until the front (anterior) of the cranium is felt. Repeat the movement executed at the posterior end of the cranium, moving the probe laterally a few degrees to the left and to the right. Gently remove the probe. The probe entry hole should only be as large 
as the diameter of the probe in order to limit deformation. Record the time that pithing was completed and the personnel involved. To meet $\mathrm{QA} / \mathrm{QC}$ requirements, both the implementor of the pithing steps and the observer must document their roles and their findings on the log (appendix 1).

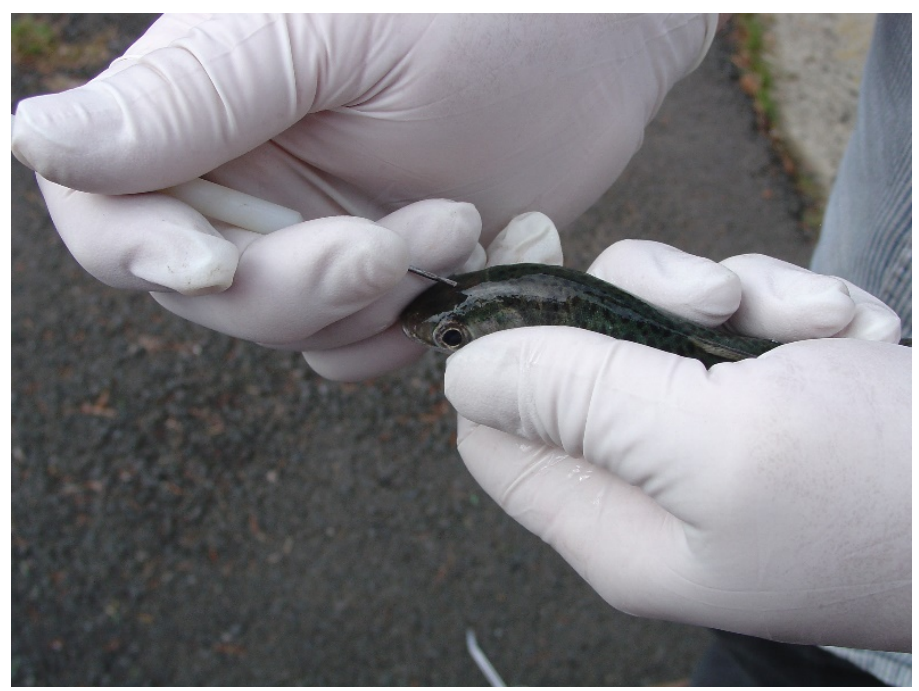

Figure 2. The initiation (first phase) of the pithing procedure on a juvenile salmon. Insert dissecting probe through the head of a juvenile salmon, between and directly behind the eyes, with the probe oriented in a posterior or caudal position.

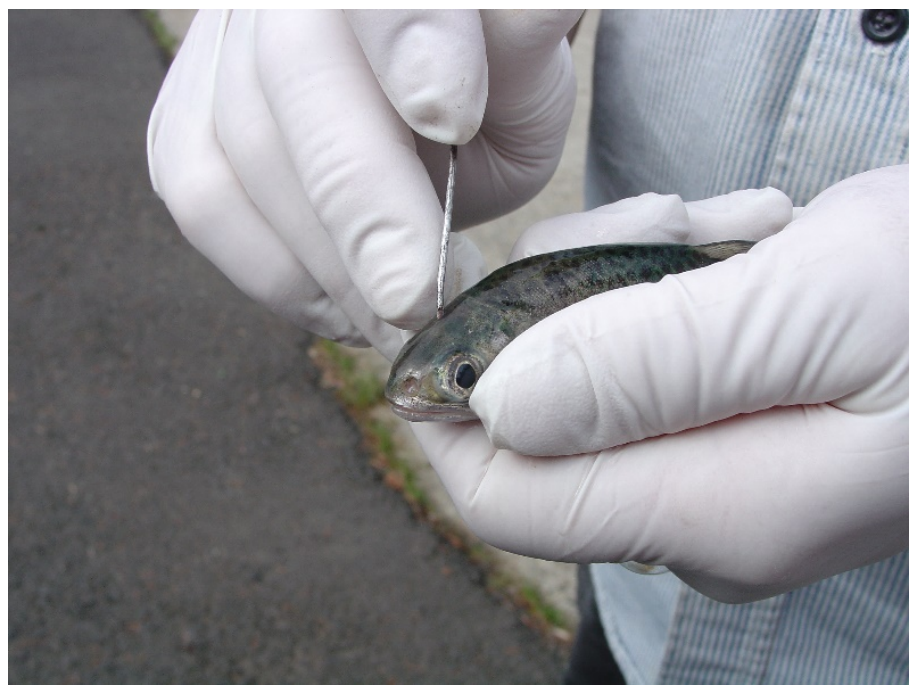

Figure 3. The second phase of the pitching procedure on a juvenile salmon. Rotate dissecting probe toward the head while remaining inserted into the cranium. 


\section{Sever Gill Arches}

The final step in the SOP is to sever all gill arches on one side of the fish to terminate all respiratory activity. Figure 4 shows a juvenile salmon positioned on its right side with the left operculum lifted and gills exposed. Juvenile salmonids have four gill arches, and due to their small size, it can be challenging to access the innermost arch. Using a set of dissecting scissors, raise the operculum (fig. 4) to get a clear view of the gills. Slide the lower scissor blade under the gill arches and cut through the cartilage of each gill arch (fig. 5). Ensure that the scissor blade is positioned under the innermost gill arch so that all arches are severed. For QA/QC, the observer must open the operculum and visually confirm that all four arches have been severed (fig. 6), and both the implementer and observer must document their observations on the log (appendix 1). Rinsing the gill area with water is useful to improve visibility, and the scissor blades can be moved between the cut arches to confirm all are indeed separated. Following QA/QC inspection, the fish is returned to the recovery container and is ready to be released with live study fish.

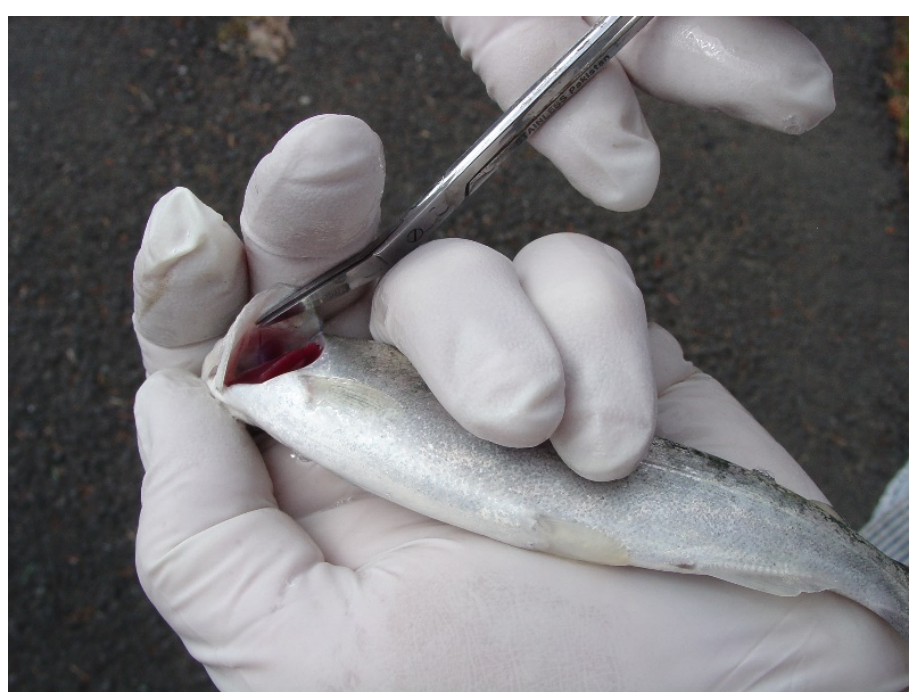

Figure 4. Juvenile salmon placement for severing gill arches. Place juvenile salmon on its right side with the head secured between the index finger and thumb, then use scissors to lift the operculum and view the gill arches in preparation for severing of gill arches. 


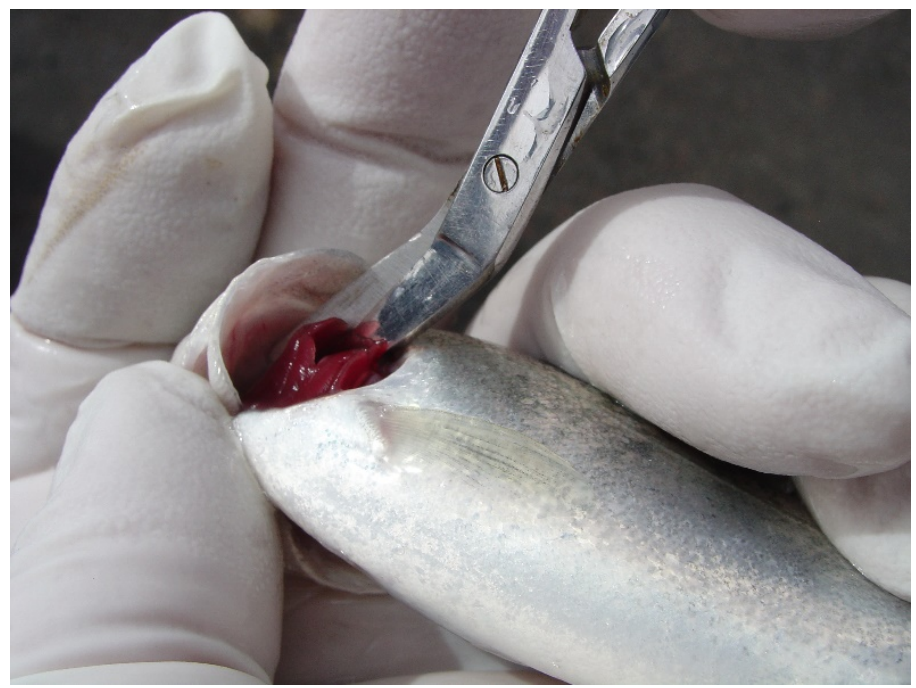

Figure 5. Scissors being used to sever the gill arches of a juvenile salmon.

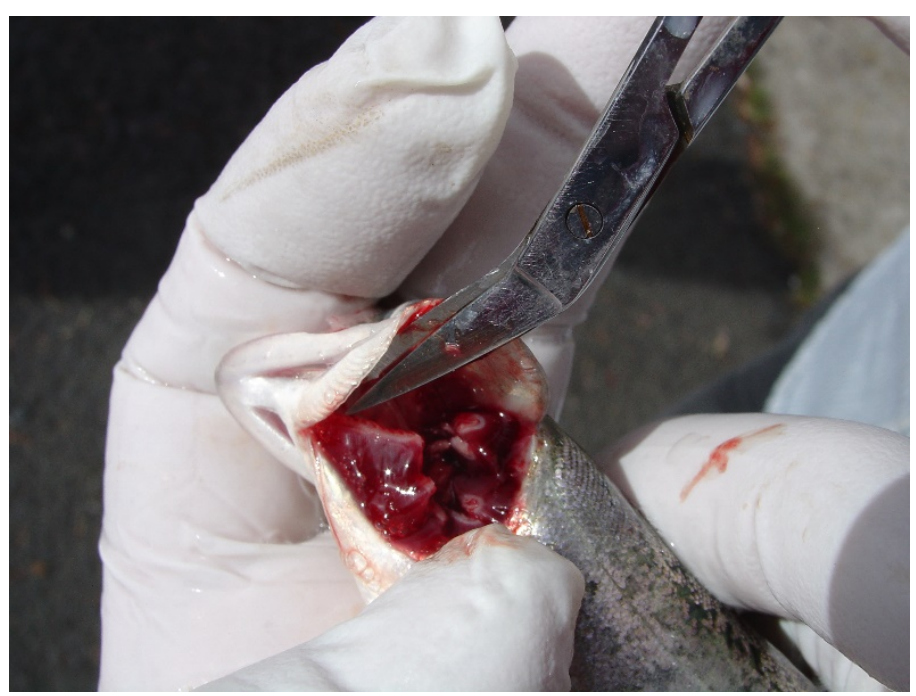

Figure 6. A juvenile salmon with four severed gill arches.

\section{Summary}

Telemetry is commonly used to monitor the movements and behavior of animals and to describe fates and mortality rates. Telemetry data can be used within a mark-recapture framework to estimate survival; however, such an approach relies on several assumptions. One critical assumption is that all detections are of live animals. Dead animals must not be detected and interpreted as being alive. In the Columbia River Basin, telemetry has been used on a large scale to estimate the survival of juvenile Pacific salmon (Oncorhynchus spp.) as they move downstream past a series of hydroelectric dams. One approach used to test the assumption that only live fish are detected at monitoring stations is to release and monitor tagged fish that are purposely killed. This document provides guidelines and a standard operating procedure (SOP) for dead fish releases where fish are exposed to three euthanization methods: high dose 
anesthetic, pithing, and severing of all gill arches. The SOP is defined specifically for juvenile salmonids and can be applied with any type of telemetry technology (for example, radio, acoustic, or passive) as well as a range of transmitter attachment techniques (for example, surgical implantation, gastric insertion, or external attachment). The described procedures can be adapted for other species or life stages using the general considerations described in this document. Methods for fish selection, tagging, releases, and quality assurance-quality control are described to ensure that fish used for dead fish releases are treated comparably to fish that are released alive.

This SOP does not purport to describe the single best procedure for dead fish releases. The purpose of this document is to share the procedures that have allowed the U.S. Geological Survey, Columbia River Research Laboratory to reliably use dead fish releases to test survival model assumptions. There are a variety of approaches that could be used to achieve similar, reliable results. In general, our experience matches those of other researchers that have used several euthanization methods in combination to be sure fish cannot revive after they are released. Using this SOP, no fish have been documented to revive in laboratory or field evaluations. Because there is no single SOP that fits all situations, each researcher must adopt procedures that are defensible on the basis of their experimental evidence, experience, or the scientific literature.

\section{Acknowledgments}

The development and refinement of this standard operating procedure would not have been possible without the assistance of a large group of current and former U.S. Geological Survey, Columbia River Research Laboratory staff over a number of years. Special thanks to Noah Adams, John Beeman, Tim Counihan, Russell Perry, and Dennis Rondorf who managed the studies that developed and used the standard operating procedure. Jill Cole, Adam Daniel, Israel Duran, Brian Ekstrom, Lisa Gee, Toby Kock, Will Simpson, Jamie Sprando, and Leah Sullivan provided invaluable assistance executing the standard operating procedure in support of field studies.

\section{References Cited}

Beeman, J.W., Braatz, A.C., Hansel, H.C., Fielding, S.D., Haner, P.V., Hansen, G.S., Shurtleff, D.J., Sprando, J.M., and Rondorf, D.W., 2010, Approach, passage, and survival of juvenile salmonids at Little Goose Dam, Washington-Post-construction evaluation of a temporary spillway weir, 2009: U.S. Geological Survey Open-File Report 2010-1224, 102 p., http://pubs.usgs.gov/of/2010/1224/.

Beeman, J.W., Hansen, A.C., Evans, S.E., Haner, P.V., Hansel, H.C., and Smith, C.D., 2012, Passage probabilities of juvenile Chinook salmon through the powerhouse and regulating outlet at Cougar Dam, Oregon, 2011: U.S. Geological Survey Open-File Report 2012-1250, 26 p., http://pubs.usgs.gov/of/2012/1250/.

Counihan, T.D., Hardiman, J.M., Walker, C.E., Puls, A.L., and Holmberg, G.S., 2006a, Survival estimates of migrant juvenile salmonids through Bonneville Dam using radiotelemetry, 2004: U.S. Geological Survey Annual Report, prepared for the U.S. Army Corps of Engineers, Portland, Oregon, contract number W66KZ40420056. 
Counihan, T.D., Puls, A.L., Walker, C.E., Hardiman, J.M., and Holmberg, G.S., 2006b, Survival estimates of migrant juvenile salmonids through the Dalles Dam using radiotelemetry, 2004: U.S. Geological Survey Annual Report, prepared for the U.S. Army Corps of Engineers, Portland, Oregon, contract number W66QKZ40369527.

Havn, T.B., Økland, F., Teichert, A.K., Heermann, L., Borcherding, J., Sather, S.A., Tambets, M., Diserud, O.H., and Thorstad, E.B., 2017, Movements of dead fish in rivers: Animal Biotelemetry, v. 5, no. 7, 9 p.

Liedtke, T.L., Beeman, J.W., and Gee, L.P., 2012, A standard operating procedure for the surgical implantation of transmitters in juvenile salmonids: U.S. Geological Survey Open-File Report 2012-1267, 50 p., https://doi.org/10.3133/ofr20121267.

Liedtke, T.L., and Wargo-Rub, M.W., 2012, Techniques for telemetry transmitter attachment and evaluation of transmitter effects on fish performance, in Adams, N.S., and others, eds., Telemetry techniques - A user guide for fisheries research: Bethesda, Md., American Fisheries Society, p. 45-88.

Perry, R.W., Braatz, A.C., Fielding, S.D., Lucchesi, J.N., Plumb, J.M., Adams, N.S., and Rondorf, D.W., 2006, Survival and migration behavior of juvenile salmonids at McNary Dam, 2004: U.S. Geological Survey Annual Report, prepared for the U.S. Army Corps of Engineers, Walla Walla, Washington, contract number W68SBV40271050.

Perry, R.W., Castro-Santos, T., Holbrook, C.M., and Sandford, B.P., 2012, Using mark-recapture models to estimate survival from telemetry data, in Adams, N.S., and others, eds., Telemetry techniques - A user guide for fisheries research: Bethesda, Md., American Fisheries Society, p. 453-476. 


\section{Appendix 1. An Example Quality Assurance/Quality Control Dead Fish Standard Operating Procedure Log}

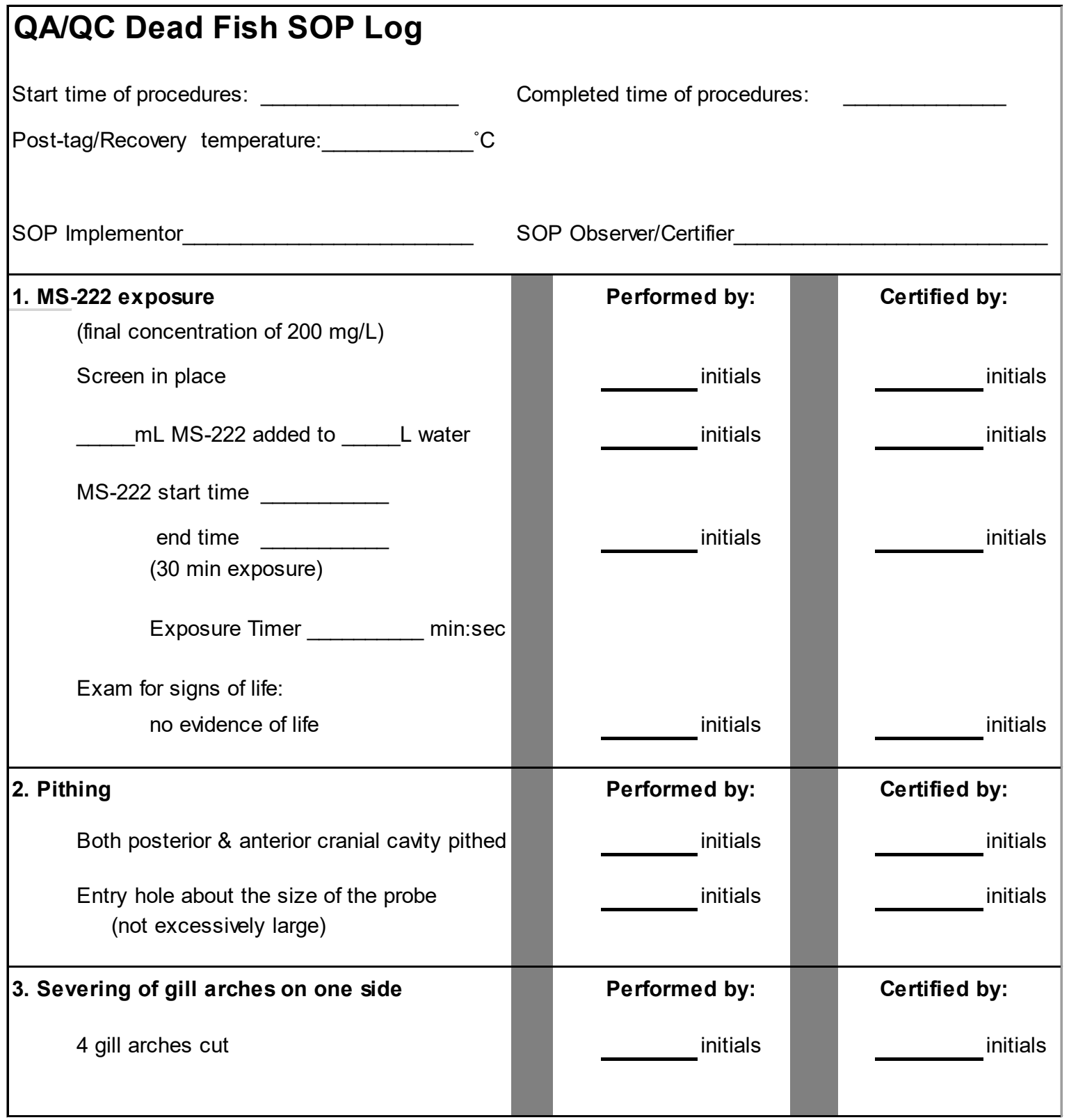



Publishing support provided by the U.S. Geological Survey Science Publishing Network, Tacoma Publishing Service Center

For more information concerning the research in this report, contact the Director, Western Fisheries Research Center

U.S. Geological Survey 6505 NE 65th Street

Seattle, Washington 98115-5016

https://www.usgs.gov/centers/wfrc 


\section{$\frac{1}{80}$}

